\title{
IN-LINE EMBROIDERY TECHNIQUE FOR CREATIVE DEVELOPMENT AND MOTOR APPLICABLE IN HIGH SCHOOL ART EDUCATION CLASSES
}

\section{ORIGINAL ARTICLE}

DUTRA, Ana Paula de Souza ${ }^{1}$, FECURY, Amanda Alves², DENDASCK, Carla Viana ${ }^{3}$, OLIVEIRA, Euzébio de ${ }^{4}$, DIAS, Claudio Alberto Gellis de Mattos ${ }^{5}$

DUTRA, Ana Paula de Souza. Et al. In-line embroidery technique for creative development and motor applicable in high school art education classes. Revista Científica Multidisciplinar Núcleo do Conhecimento. Year 06, Ed. 01, Vol. 08, pp. 26-33. January 2021. ISSN: 2448-0959, Access Link: https://www.nucleodoconhecimento.com.br/education/embroidery-technique, DOI: 10.32749/nucleodoconhecimento.com.br/education/embroidery-technique

\section{SUMMARY}

Artistic education is composed of several techniques that lead to the development of logical thinking, creativity and motor coordination. The aim of this work is to describe an in-line embroidery technique for creative development and motor applicable in high school art education classes. The method described will be free embroidery images, a technique that uses fabric, needle and threads, as well as images. The use

\footnotetext{
${ }^{1}$ Graduated in Fine Arts (FAAP SP), studying Specialization in Arts, Rudolf Steiner College (FRS SP).

${ }^{2}$ Biomedical, PhD in Tropical Diseases, Professor and researcher of the Medical Course of Macapá Campus, Federal University of Amapá (UNIFAP).

${ }^{3}$ Theologian, PhD in Clinical Psychoanalysis. She has been working with Scientific Methodology for 15 years (Research Method) in the Scientific Production Orientation of Master's and PhD students.Specialist in Market Research and Research focused on the Health area.

${ }^{4}$ Biologist, PhD in Tropical Diseases, Professor and researcher of the Physical Education Course, Federal University of Pará (UFPA).

${ }^{5}$ Biologist, PhD in Theory and Behavior Research, Professor and researcher of the Chemistry Degree Course of the Institute of Basic, Technical and Technological Education of Amapá (IFAP) and the Graduate Program in Professional and Technological Education (PROFEPT IFAP).
}

RC: 73420

Disponível em: https://www.nucleodoconhecimento.com.br/education/embroidery- 
of the technique of free embroidery - Images described may be able to provide high school students with a greater development in the capacities of concentration (focus, attention), motricity and creativity. The technique of respecting the individual in his individuality of learning and ludicity also seems to influence the increase of these capacities. The described technique can be quietly adapted to different regions, as happens in Brazil, a country of continental dimensions and unprecedented diversity.

Keywords: Free Embroidery, Motricity, Concentration, Creativity.

\section{INTRODUCTION}

Within the Brazilian educational curriculum there is a component called artistic education (BRASIL, 1997). Artistic education is composed of several techniques that lead to the development of logical thinking, creativity and motor coordination, using the expression of feeling (EÇA, 2010). Among these techniques there are manual works, so-called because they are carried out with their hands (RAMOS, 2013), such as painting, embroidery, crochet, macramê and crafts (GUEDES et al., 2011).

It is possible to produce different types of manual work (GUEDES et al., 2011). Crafts is a group of manual works carried out with different components creating the most varied forms (painting, embroidery, crochet, macramê, basketry, ceramics) (RAMOS, 2013). In painting, paints or other printing mode are usually used, and a substrate (paper, wood, canvas, etc.) to make the graphic representation of an image (CASTILHO et al., 2017). In embroidery a fabric is used as a base where the set of different needles and threads perform finishes with geometric shapes or figures (RAMOS, 2013).

In elementary and high schools it seems to be more than appropriate the teaching of manual work. Crafts work interdisciplinarity, an important concept for the global acquisition of knowledge. It also stimulates creativity and problem solving. This

RC: 73420

Disponível em: https://www.nucleodoconhecimento.com.br/education/embroidery- 
results in a humanized citizen who better understands the other and the world (TEIXEIRA, 2020).

There are different types of manual work that can be used in teaching. Among them, cross stitch embroidery, crochet and knitting are handwork that use lines of various types braided with different needles and are taught since childhood in various regions of Brazil (ALMEIDA, 2003; SANTOS et al., 2012). The macramê uses different types of braided yarns (sisal, string) for different shapes objects (supports of vases, curtains, embellishments) (VERMA et al., 2019).

To develop these works there are several different embroidery techniques. Among them the technique of free embroidery where each person edge according to their creativity, without pre-established parameters (MENDONÇA and AGUIAR, 2015).

Manual work, such as embroidery, for example, stimulates the motor capacity of children by making them use the musculature in movements called fine. The concentration is also amplified in students with this school practice. (TEIXEIRA, 2018).

Online work stimulates and increases creativity in students. The personal expression where the reproduction of images and creation are intertwined stimulates both knowledge and creation itself (BERGAMO and SILVA, 2020)

\section{GOAL}

Describe an in-line embroidery technique for creative development and motor applicable in high school art education classes.

\section{MATERIAL AND METHOD}

\section{MATERIALS}

$\mathrm{RC}: 73420$

Disponível em: https://www.nucleodoconhecimento.com.br/education/embroidery- 
- Cotton fabric $50 \mathrm{~cm} \times 50$ centimeters, one per student;

- Wooden rack of 30 centimeters, one per student;

- Varied colored lines, 08 meters per student;

- Lines of varied colored skeins, 08 meters per student;

- Needles for embroidery numbers 22 and 24 for cross stitch, one pair for each student;

- Trim scissors, one for each student;

- Select two (varied) images per student and print them in black and white in size 14 centimeters by 10 centimeters (1/4 of $A 4$ paper).

\section{METHOD}

Free Embroidery Technique - Images

This technique is applied and finished in four classes of 50 minutes each. Classes must have a maximum number of 10 students.

The materials listed must be arranged in front of each student at the beginning of the lesson. Printed images should be placed in random pairs along with the rest of the materials. Both images and lines can be exchanged between students. The images only at the beginning of the application of the technique, and the lines at any time during the classes.

Step 1: The image to be worked on must be chosen by each student, among the images available.

RC: 73420

Disponível em: https://www.nucleodoconhecimento.com.br/education/embroiderytechnique 
Step 2: Each cotton fabric $(50 \times 50 \mathrm{~cm})$ should be placed in the wooden rack $(30 \mathrm{~cm})$, leaving it as stretched as possible (Figure 1).

Figure 1 Shows the rack $(A)$, the cotton fabric $(B)$ and the fabric inside the rack $(C)$.
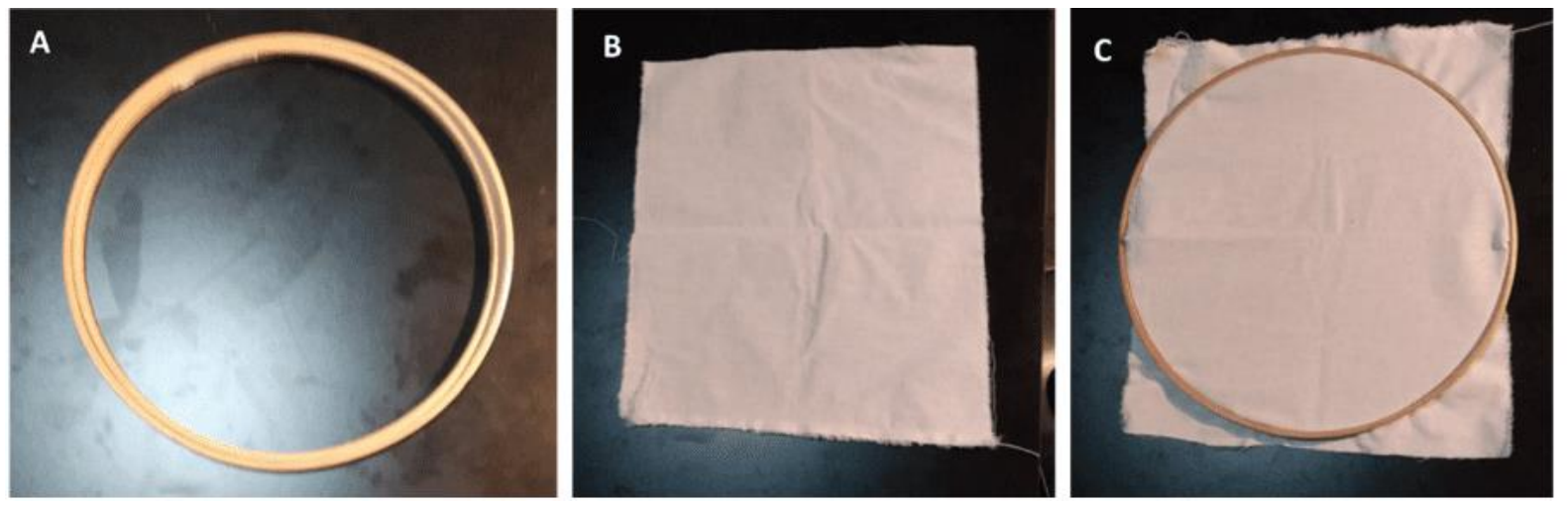

Step 3: Students must select the colors and line types (which can be both types) to use. These lines can be socialized during the process (Figure 2).

RC: 73420

Disponível em: https://www.nucleodoconhecimento.com.br/education/embroiderytechnique 
Figure 2 Shows examples of cotton threads that can be used.

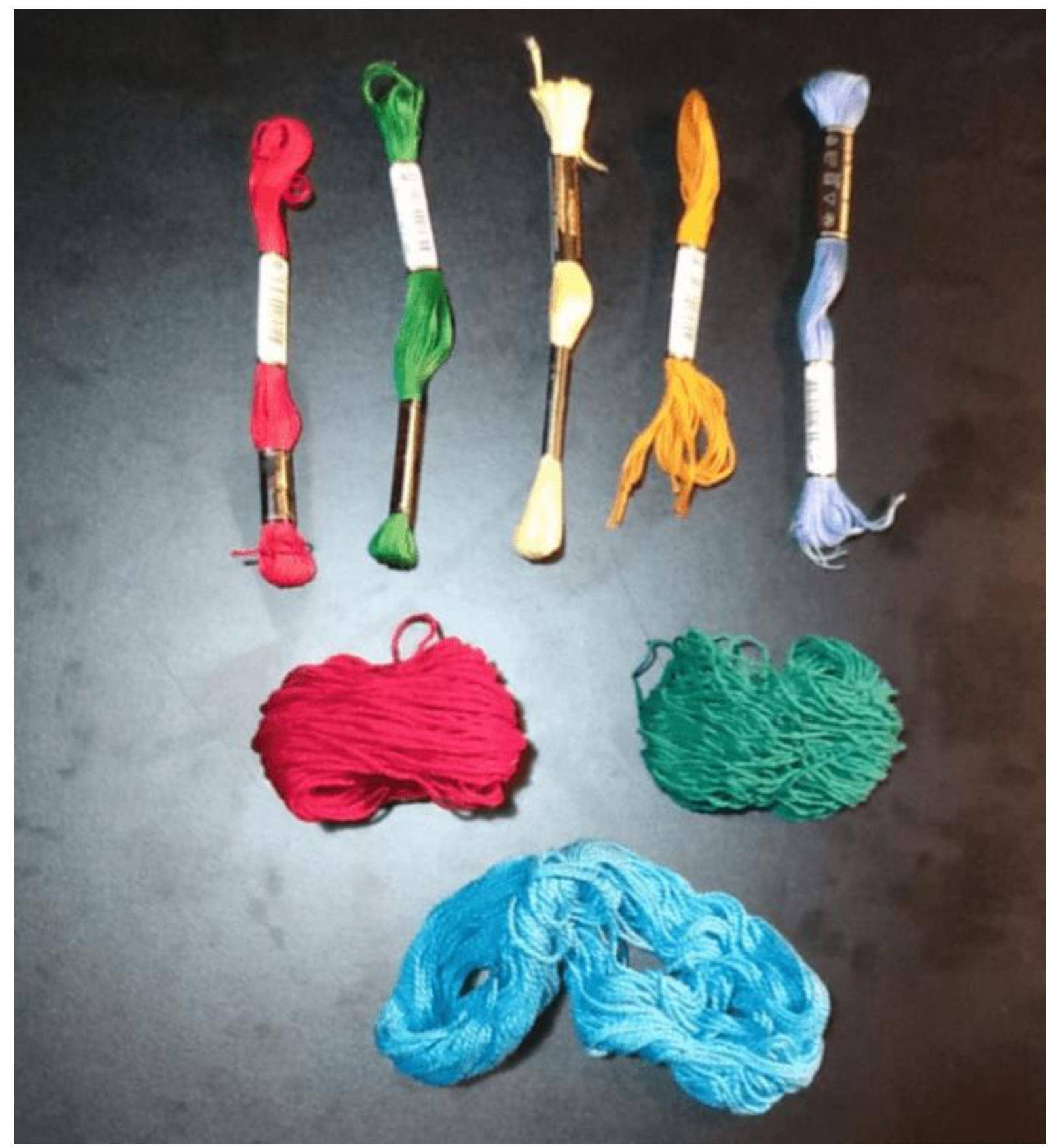

Step 4: Each student cuts $40 \mathrm{~cm}$ pieces of the lines (type and color) chosen to perform the work. Lines can be switched or not during the process.

RC: 73420

Disponível em: https://www.nucleodoconhecimento.com.br/education/embroiderytechnique 
Step5: Each student chooses between available embroidery needles (22 or 24) and places the first of the lines in this (Figure 3).

Figure 3 Shows the cedgeneedles numbers $22(\mathrm{~A})$ and 24 (B)

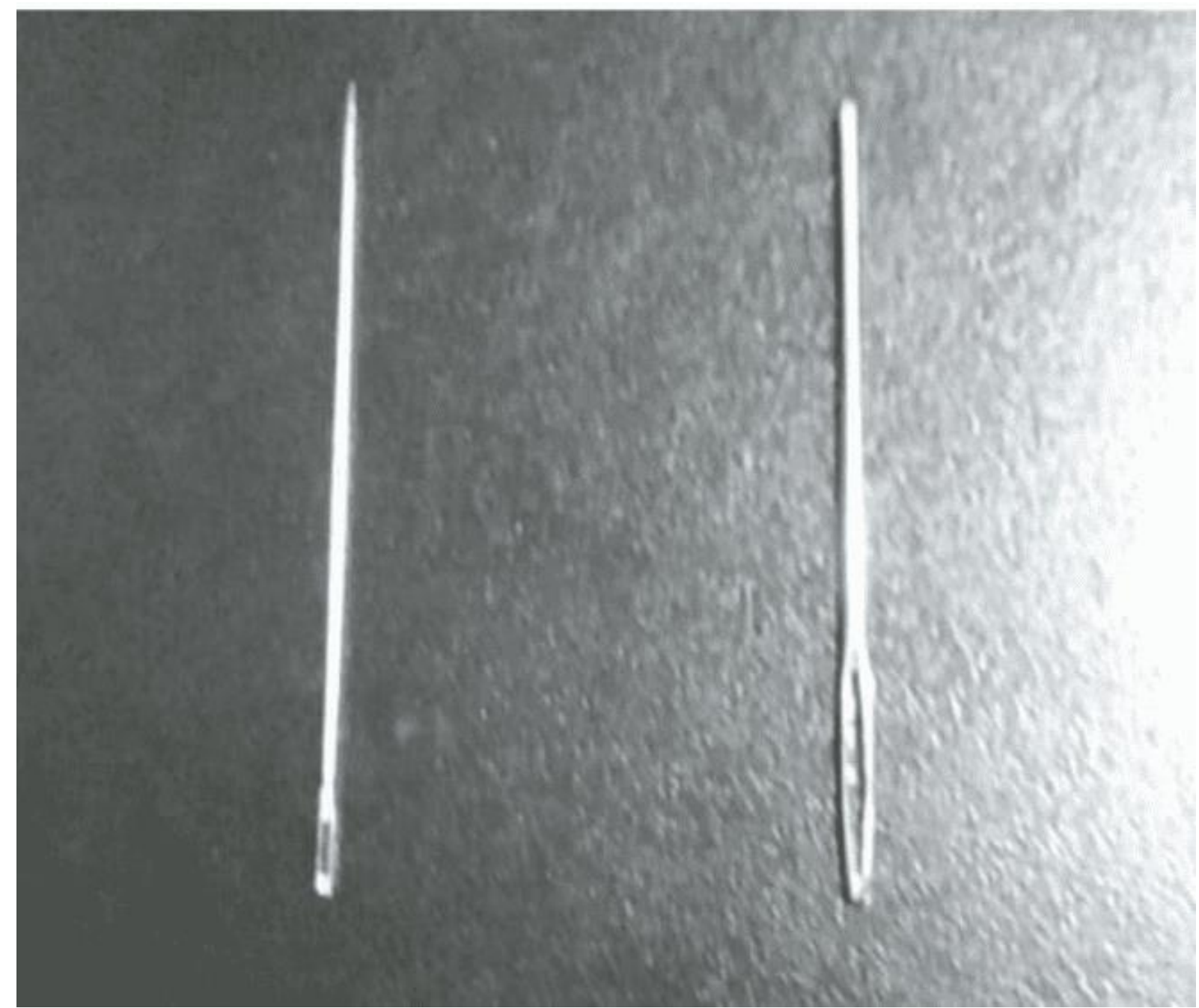

Step 6: The teacher exemplifies in a fabric, placed in a backstage, the point called "Behind". This point will be made in large size and with red line for better viewing. The teacher will teach students the possible sizes of this type of point (Figure 4).

Figure 4 Shows the steps of making the "Back" stitch, with cotton fabric thread attached to wooden rack.

RC: 73420

Disponível em: https://www.nucleodoconhecimento.com.br/education/embroiderytechnique 

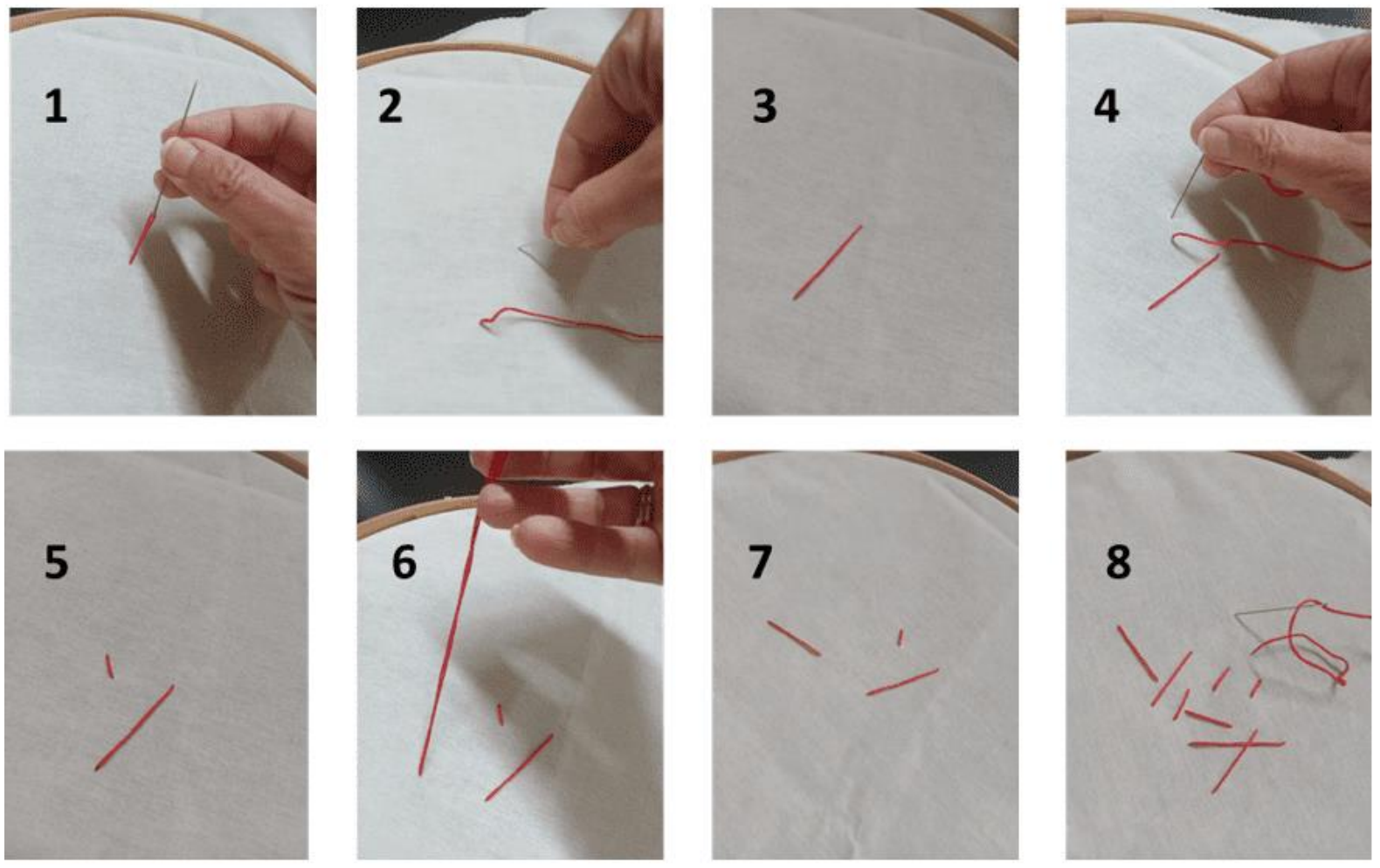

Step7: Each student should place in front of them the image they have previously chosen.

Step 8: From the observation of the image each student should try to reproduce the image or a free interpretation of it in the fabric, using the point type 'Behind'. It should also choose the different point sizes, using a single size or alternating them.

\section{EXPECTED RESULTS}

It is expected that, in the end of the period, each student will finish their representation with thread in the fabric. Students should also present evolution in their ability to observe (concentration, focus) motor and creative.

RC: 73420

Disponível em: https://www.nucleodoconhecimento.com.br/education/embroiderytechnique 


\section{DISCUSSION}

The act of teaching and learning has become a rational and mechanical, conceptual path, giving up what is subjective, playful and aesthetic. In modern adolescent students, psychoemotional factors seem to influence the formation of thoughts and, thus, on learning. Waldorf pedagogy then advocates the enrichment of learning (concentration) through artistic activities and experiences. The contents of the disciplines are linked to a practice (artisanal activities, for example) and to an artistic activity (called didactic vehicle) (SILVA, 2015).

In a school with the Waldorf philosophy, you teach students manual labor. Tenth-year teenagers, according to the school curriculum, are able to design handmade objects using tapestry techniques. This requires the student's motor skills and a high concentration (LUZ, 2016).

There are students who have a syndrome that brings together attention deficit, motor deficit and perception deficit, called MPD syndrome. Research shows that individuals with difficulties in the areas of attention (concentration, focus), motricity (coarse and fine) and language, when exposed to teaching that privileges the expression of freedom and artistic components, including manual works, tend to present improvement in their paintings. Concentration (attention), motricity and social interaction are enhanced (SOUSA, 2011).

A single-subject case study conducted over a period of two years demonstrated that the human being develops an eye-to-hand coordination, indispensable for writing. This type of coordination is the same that is acquired and automated when learning and mastering the techniques of manual work with line, for example. For the learning and mastery of this motricity it is necessary to practice, as it is done in arts classes (PATERNOST, 2000).

RC: 73420

Disponível em: https://www.nucleodoconhecimento.com.br/education/embroidery- 
Students with writing difficulties (dysgraphia) usually have normal or above-standard intelligence. The difficulty they present hinders, however, their school performance. The process of using manual work with this student (knitting, crocheting and weaving), associated with the diversity of spaces and freedom of imagination (Waldorf method), enables physical experiences that help in the improvement of this picture (FONSECA et al., 2020).

A report Portuguese on supervised teaching, conducted with primary and secondary education classes, demonstrates that students can develop their creativity through several different techniques, including manual work. Among the types of work appear the works with lines (crochet and knitting) (GOUVEIA, 2012).

Adolescents with longer exposure time to virtual life have some deficiencies when compared to adolescents who have shorter exposure time. Motor activity is lower in individuals who are closely linked to activities with screen than those who practice physical activities (sports). Time spent on virtual games, for example, can cause a fall in concentration linked to calm thinking and contemplation. Virtual activities also seem to provide a fall in creativity, to the detriment of those who use manual activities (SETZER, 2014).

\section{CONCLUSION}

The use of the technique of free embroidery - Images described may be able to provide high school students with a greater development in the capacities of concentration (focus, attention), motricity and creativity.

The technique of respecting the individual in his individuality of learning and ludicity also seems to influence the increase of these capacities.

The described technique can be quietly adapted to different regions, as happens in Brazil, a country of continental dimensions and unprecedented diversity.

RC: 73420

Disponível em: https://www.nucleodoconhecimento.com.br/education/embroidery- 


\section{REFERENCES}

ALMEIDA, R. N. M. D. Plano de negócios de uma loja de artigos para tircô, crochê e bordado ponto cruz. 2003. 123p. (Graduação). Universidade Federal de Santa Catarina, Florianópolis SC.

BERGAMO, M. L.; SILVA, A. L. Doilies Digitais: Um Estudo da Aplicação de Criatividade Computacional ao Crochê. DATJournal, v. 5, n. 1, p. 138-152, 2020.

BRASIL. Parâmetros curriculares nacionais: arte / Secretaria de Educação Fundamental. SEF. Brasília DF: MEC/SEF: 130p. p. 1997.

CASTILHO, M. A. et al. Artesanato e saberes locais no contexto do desenvolvimento local. Interações (Campo Grande), v. 18, n. 3, 2017.

EÇA, T. T. A Educação Artística e as Prioridades Educativas do Início do Século XXI. Revista Iberoamericana de Educación, n. 52, p. 127-146, 2010.

FONSECA, S. M. D. F. P. D. et al. Coordenação motora fina: do Direito às propostas pedagógicas da Pedagogia Waldorf em disgráficos. Braz. J. of Develop., v. 6, n. 9, p. 71688-71705, 2020.

GOUVEIA, L. R. D. R. Relatório da Prática de Ensino Supervisionada em Ensino de Artes Visuais no 3ํㅡㄹ Ciclo do Ensino Básico e Secundário. Universidade de Évora. Evora PT, p.1-112. 2012

GUEDES, M. H. M.; GUEDES, H. M.; ALMEIDA, M. E. F. Efeito da prática de trabalhos manuais sobre a autoimagem de idosos. Rev. bras. geriatr. gerontol., $v$. 14, n. 4, 2011.

LUZ, I. R. P. VIVÊNCIA DA TECELAGEM MANUAL EM UMA TURMA DE 8 ANO DA ESCOLA MUNICIPAL OSÓRIO ALEIXO DA SILVA. 2016. 85p.

RC: 73420

Disponível em: https://www.nucleodoconhecimento.com.br/education/embroidery- 
(Especialização). Escola de Belas Artes da UFMG Universidade Federal de Minas Gerais, Belo Borizonte MG.

MENDONÇA, M. D.; AGUIAR, S. M. Linhas, Laços e Tramas na Terceira Idade. p. $15 \mathrm{p}$., 2015.

Disponível em:

http://www.cp2.g12.br/blog/propgpec/files/2019/11/Linhas-La\%C3\%A7os-e-Tramasna-Terceira-Idade.pdf >. Acesso em: 21 jan 2021.

PATERNOST, V. A MOTRICIDADE COMO BASE PARA A APRENDIZAGEM: O Estudo de Um Caso pela Reorganização Neurofuncional 2000. 138p. (Mestrado). UNIVERSIDADE ESTADUAL DE CAMPINAS, Campinas SP.

RAMOS, S. P. Políticas e Processos Produtivos do Artesanato Brasileiro como Atrativo de um Turismo Cultura. Revista Rosa dos Ventos v. 5, n. 1, p. 44-59, 2013

SANTOS, D. B. S. D.; SILVA, F. S. D.; CARMO, G. D. Bordadeiras da Namoradinha do Sertão: estudo sobre a produção de bordados da cidade de São João dos Patos VII CONNEPI. Palmas TO 2012.

SETZER, V. W. EFEITOS NEGATIVOS DOS MEIOS ELETRÔNICOS EM CRIANÇAS, ADOLESCENTES E ADULTOS. Sao Paulo, 2014. Disponível em: < https://www.ime.usp.br/ vwsetzer/efeitos-negativos-meios.html >. Acesso em: 21 jan 2021.

SILVA, D. A. A. E. Educação e ludicidade: um diálogo com a Pedagogia Waldorf. Educar em Revista, n. 56, p. 101-113, 2015.

SOUSA, M. D. L. C. M. D. A aplicação da pedagogia Waldorf em alunos com síndrome de DAMP. 2011. 126p. (Mestrado). Universidade Católica Portuguesa, Viseu.

RC: 73420

Disponível em: https://www.nucleodoconhecimento.com.br/education/embroidery- 
TEIXEIRA, I. A. Bordados em sala de aula. 2018. 45p. (Graduação). Universidade de Brasília, Brasília DF.

TEIXEIRA, J. V. S. A Educação Artística-uma prioridade no sistema educativo português: o contributo das expressões artísticas para o desenvolvimento integral do aluno no 1. CEB. 2020. 143 (Mestrado). Instituto Superior De Ciências Educativas Do Douro, Pènafiel.

VERMA, P.; MAHAJAN, S.; KAUR, D. Development of Macrame dresses using textile waste. International Journal of Education \& Management, v. 9, n. 3, p. 130133, 2019.

Submitted: January, 2021.

Approved: January, 2021.

RC: 73420

Disponível em: https://www.nucleodoconhecimento.com.br/education/embroiderytechnique 